\title{
Compressive Myelopathy Due to Ossification of the Ligamentum Flavum: Case Report and Review of the Literature
}

\section{Mielopatia compressiva devido à ossificação do ligamento flavo: relato de caso e revisão da literatura}

\author{
Alisson R. Teles ${ }^{1}$ Frederico A. Criscuoli de Farias ${ }^{2}$ \\ ${ }^{1}$ Department of Neurology and Neurosurgery, McGill Scoliosis \& \\ Spine Group, McGill University, Montreal, QC, Canada \\ 2 Universidade de Caxias do Sul, Caxias do Sul, RS, Brazil \\ ${ }^{3}$ Department of Neurosurgery, Universidade de Caxias do Sul, Caxias \\ do Sul, RS, Brazil \\ ${ }^{4}$ Hospital São José - Santa Casa de Porto Alegre, Porto Alegre, RS, Brazil
}

Marcelo R. Roxo ${ }^{3}$ Albert Vincent Berthier Brasil ${ }^{4}$

\begin{abstract}
Address for correspondence Alisson R. Teles, MD, Department of Neurology and Neurosurgery, McGill Scoliosis \& Spine Group, McGill University, Montreal, QC, Canada (e-mail: alisson.r.teles@gmail.com).
\end{abstract}

Arq Bras Neurocir 2017;36:117-121.

\begin{abstract}
Ossification of the ligamentum flavum (OLF) is a rare condition in which the ligamentum

Keywords

- ossification of the ligamentum flavum

- myelopathy

- paraparesis

- ligamentum flavum

- laminectomy

- thoracic spine flavum, due to mechanical, biological and genetic factors, becomes ossified. Due to its nature and anatomic location, OLF produces symptoms characteristic of spinal cord compression. The diagnostic confirmation is based primarily on imaging tests such as computed tomography (CT) and magnetic resonance imaging (MRI). Ossification of the ligamentum flavum most often affects Asian populations, rarely occurring in black people. The authors report a case of a 61-year-old black man with progressive paraparesis due to OLF, and review the literature regarding the pathology's prevalence, pathogenesis, clinical features, diagnosis, treatment and prognosis.

\section{Resumo}

Palavras-chave

- ossificação do ligamento flavo

- mielopatia

- paraparesia

- ligamento flavo

- laminectomia

- coluna torácica

A ossificação do ligamento flavo (OLF) é uma doença rara na qual o ligamento flavo se torna ossificado devido a fatores mecânicos, biológicos e genéticos. Devido à sua natureza e localização anatômica, a OLF produz sintomas característicos de compressão da medula espinhal. A confirmação diagnóstica baseia-se principalmente em exames de imagem, como tomografia computadorizada (TC) e ressonância magnética (RM). A OLF afeta mais comumente populações asiáticas, raramente sendo observada em pacientes negros. Os autores relatam o caso de um homem negro de 61 anos com paraparesia progressiva decorrente de OLF com uma revisão da literatura a respeito da prevalência, patogênese, aspectos clínicos, diagnóstico, tratamento e prognóstico desta patologia.
\end{abstract}

\section{Introduction}

Ossification of the ligamentum flavum (OLF) was first described by Polgar in 1920, and it has been recognized as a potential cause of compressive myelopathy. ${ }^{1-8}$ This entity is

received

December 30, 2016

accepted

March 16, 2017

published online

May 24, 2017 10.1055/s-0037-1603554. ISSN $0103-5355$. relatively common in Asia, with a reported prevalence in China of $4 \%$ in the general population, and of $8 \%$ in people older than $45 .^{3}$ Approximately $90 \%$ of the reports of this condition in the literature include the Japanese population. $2,3,6,9$

Copyright (e 2017 by Thieme Revinter

Publicações Ltda, Rio de Janeiro, Brazil

License terms

c) $(1) \$$ 
It has been suggested that a genetic component may explain the increased prevalence of OLF in certain ethnic and racial groups. ${ }^{10-12}$ Despite this evident geographic distribution, some authors have reported OLF in Caucasians, ${ }^{13-15}$ Hispanics, ${ }^{1,16,17}$ Afro-Caribbeans, ${ }^{6,18}$ as well as in subjects from the Middle East, ${ }^{19}$ India, ${ }^{20,21}$ North Africa, ${ }^{2,22}$ North America, ${ }^{23}$ and South America. ${ }^{24}$

The aim of the authors is to review the literature concerning the epidemiology, natural history, treatment strategies and prognosis of this relatively uncommon disease, and to present a case of OLF causing compressive myelopathy in a Brazilian patient.

\section{Case Report}

A 61-year-old black man presented with progressive paraparesis over a period of 5 years. Two years ago, he started walking with crutches and complaining of urinary incontinence, and over the past two months he was bound to a chair. In the past four months, he noticed successive transient electric-like shocks in the back triggered by trunk extension, as well as spasms on both lower limbs. No intestinal or sexual dysfunctions were reported. A neurological examination revealed a sensory level at T10, and loss of position sense in both lower extremities. A lower extremity motor examination revealed a left side weakness greater than the right side one, grading $2 / 5$ and $3 / 5$ respectively, associated with spasticity, clonus, and Babinski sign bilaterally.
Due to the severe obesity of the patient, magnetic resonance imaging (MRI) could not be performed. The patient underwent a computed tomography myelogram (CT-M), which demonstrated a significant thoracic spinal stenosis in T10-T11 due to OLF (-Fig. 1). No spinal instability was observed, and there was no stenosis among the other levels.

The patient was submitted to a surgical procedure. It consisted of T10-T11 laminectomies and removal of an ossified ligamentum flavum by microsurgical technique, with wide spinal canal decompression in this level. Due to obesity, the patient was operated in the lateral position on the surgical table. A posterior midline subperiosteal dissection was performed, and the T9 (partially), T10 and T11 laminas were exposed. Using a 3-mm burr and Kerrison punches, we started the decompression at the superior part of the T10 lamina until exposure of the dura mater. Subsequently, a partial laminectomy of the T11 lamina was performed, and the dura mater bellow the calcified ligament was exposed. Finally, the T10T11 OLF was removed using a careful microsurgical technique. There was no intraoperative complication. At the end of the decompression, the dura expanded to fill the laminectomy, and was noted to be pulsatile. No intraoperative neurophysiological monitoring was used in this case. There was no postoperative complication. A progressive improvement in strength was observed immediately after the surgery. Twelve months' follow-up revealed persistent spasticity and hypoesthesia in the lower limbs, and the patient returned to walk without assistance with a mild spastic gait.
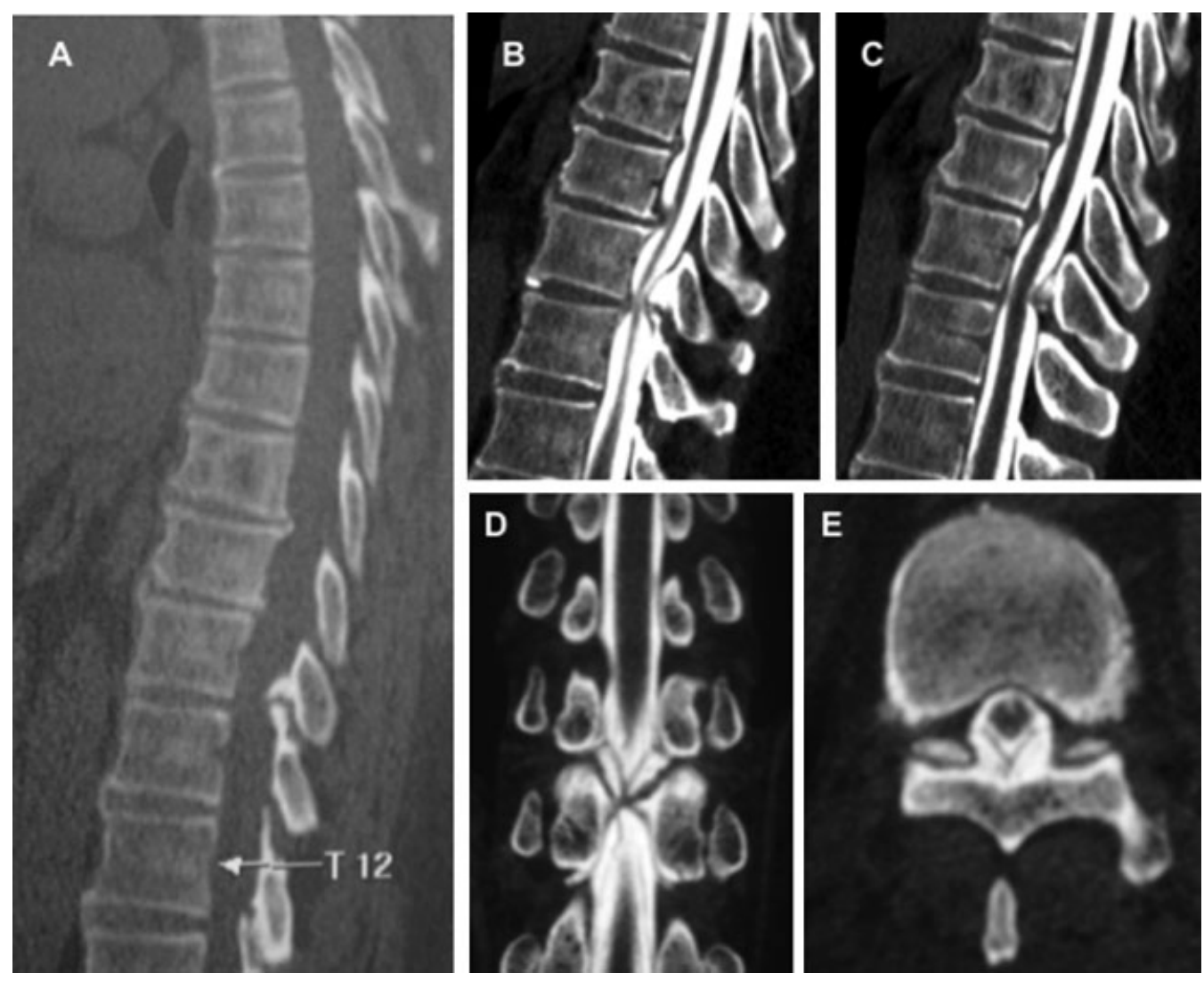

Fig. 1 (A) Computed tomography (CT) scan showing ossification of the ligamentum flavum (OLF) at T10-T11. Sagittal (B, C), coronal (D) and axial (E) CT myelogram demonstrating significant thoracic spinal stenosis in T10-T11 due to OLF. 


\section{Discussion}

The ligamentum flavum consists of a group of paired ligaments that connect adjacent spinal column laminae, extending from $\mathrm{C} 2$ to $\mathrm{S} 1 .{ }^{1}$ In OLF, the ligamentum flavum becomes ossified through a process of ectopic bone formation, which occurs through hypertrophy of the ligament, proliferation of chondrocytes and ossification, characterizing a process of endochondral ossification. ${ }^{25,26}$

Even though 90 years have passed since its first description, the pathophysiology of OLF is not yet totally understood. ${ }^{14}$ Many authors have postulated that it derives broadly from mechanical stress, but other metabolic and genetic factors may also be of relevance., 10,11,27-32 Histologically, the lesion often presents with degeneration and disorganization of elastic fibers. ${ }^{12,25,26,33,34}$ Yoshida et $\mathrm{al}^{33}$ and Yayama et $\mathrm{al}^{12}$ have shown increased production of collagen fibers in the lesion. Several authors demonstrated that altered expression of bone morphogenetic protein (BMP-2), transforming growth factor $\beta$ (TGF- $\beta$ ) may play a role in the process that leads to OLF. ${ }^{12,27,28}$ It has been shown that genetic polymorphism in collagen-related genes may also contribute in that aspect. ${ }^{29,30}$ Although OLF has been reported as an isolated form of spinal column ossification, many publications proposed the existence of an interrelation with conditions such as diffuse idiopathic skeletal hyperostosis (DISH), ankylosing spondylitis, and metabolic disorders. Disorders such as hypoparathyroidism, X-linked hypophosphatemia, Paget's disease, vitamin Dresistant rickets, non-insulin-dependent diabetes mellitus, and calcium and fluoride derangements, as well as other spinal ligamentous ossifications. ${ }^{4,5,20,34-46}$ Finally, it has been suggested that the genetic background may explain the increased prevalence of OLF in certain ethnic and racial groups. ${ }^{10-12}$

Ossification of the ligamentum flavum is a major cause of myelopathy in Japan. An epidemiological study conducted by Sato et al in Japan showed that $64 \%$ of surgeries for thoracic myelopathy were due to OLF. ${ }^{47}$ Another similar study in Japan showed the presence of OLF in $52 \%$ of thoracic myelopathy surgical procedures. ${ }^{48}$ Guo et $\mathrm{al}^{3}$ reported the prevalence of OLF in 1,736 Chinese volunteers using the MRI. They demonstrated a prevalence of OLF in 3.8\% (66 volunteers) of the sample. Of the 92 affected segments, 87 (94.5\%) were located in the thoracic region, with more than half of those (48 segments) located on the lower thoracic spine. In that study, isolated OLF was present in $68.2 \%$ of the cases, with continuous and non-continuous multilevel lesions present in $16.7 \%$ and $15.2 \%$ of the cases respectively.

Several other authors have asserted the isolated form as the most prevalent, and that the lower thoracic spine, specially T9-T10 and T10-T11, is the most affected region. ${ }^{1,2,6,12,14,49}$ These data are also supported by a review published by $\mathrm{Xu}$ et al. ${ }^{14}$ This prevalence occurs probably because this transitional level presents a high load and less anatomic protection from the rib cage, making it more prone to degenerative processes and mechanical stress, which in turn leads to ossification. ${ }^{3,31,32}$
Ossification of the ligamentum flavum is very rare among black patients, with only a few reports in the literature. ${ }^{8,50-54}$ In 1998, Pascal-Mousselard et al reported an unusual OLF in the thoracic spine in a black patient presenting with progressive spastic paraparesis. ${ }^{8}$ Because of its rarity in black patients, OLF is a diagnosis of exclusion in this population.

When OLF lesions are small, patients may be asymptomatic. $^{3}$ Once the lesions grow enough to significantly affect the spinal canal, patients often present with symptoms secondary to myelopathy. These include motor and sensory dysfunctions and bladder impairment. ${ }^{1,2}$ Since the majority of these cases occurs at lower thoracic levels, ${ }^{5,55}$ the most common symptoms are uni- or bilateral lower limb weakness, ${ }^{2,6,8,12,14,18,56}$ pain $^{6,8,18,56}$ and sensorial loss, ${ }^{2,6,8,56}$ unsteady gait, ${ }^{6,8,14}$ brisk reflexes with positive Babinski, ${ }^{8,56}$ and urinary frequency and urgency, often accompanied by incontinence. ${ }^{6,8,14,18,56}$ In cases in which OLF presents at upper levels, upper limb and neck involvement may occur. ${ }^{1,6}$ Advanced OLF can also cause paraplegia, as reported by Ben Hamouda et $\mathrm{al}^{2}$ and Okada. ${ }^{5}$

Plain radiographs are not sensitive enough to diagnose OLF in most of the cases, since its radiopaque shadow can be obscured by bony structures. ${ }^{4}$ Computed tomography and MRI are the best imaging modalities to establish the diagnosis. ${ }^{14}$ Computed tomography is more accurate, ${ }^{14}$ revealing characteristic intense radiodense lines along the laminae. ${ }^{1,6}$ The lesion most commonly presents in a $\mathrm{V}$-shaped fashion on axial imaging, ${ }^{1,2,6}$ but it may also present as nodular, moundshaped lesions. ${ }^{14,57}$ The $\mathrm{CT}$ is also useful in determining if the dura-mater is involved in the OLF or not. ${ }^{1}$ Both the T1- and T2-wheigted MRIs are used mostly to evaluate spinal cord involvement, showing a hyperintense signal in the affected parts. ${ }^{1,2,6,15,58}$. The ossification itself presents a hypointense signal in this imaging modality. ${ }^{2,3,14} \mathrm{~A}$ myelogram can determine the presence of spinal cord compression, but it often fails to define the nature of the lesion. Thus, the myelogram is often accompanied by CT imaging., ${ }^{2,8} \mathrm{~A}$ retrospective analysis by Muthukumar et al ${ }^{59}$ established two radiological signs of dural ossification related to OLF: the "tram track sign" and the "comma sign." The former consists of a hyperdense bony excrescence with a hypodense center, with the latter being evidence of ossification on one half of the circumference of the dura mater. ${ }^{59}$

Ossification of the ligamentum flavum can often be confused with calcification of the ligamentum flavum $(\mathrm{CLF}),{ }^{2,6}$ which is a rare disease that occurs through a deposit of calcified granules along the ligamentum flavum, with no bone formation. ${ }^{2}$ Since both lesions appear as hypointense formations on the T1- and T2-weighted MRIs, the diagnosis can be confirmed according to CT imaging, with CLF being discontinuous with the laminae, opposite to OLF. ${ }^{3,4,14,60}$ It's also worth noting that the majority of cases of CLF occur in the cervical spine. ${ }^{2,61}$

To this date, there are no efficient pharmacological therapies to treat OLF. $^{14}$ Due to the nature of the disease, the treatment consists mostly of simple surgical decompression. ${ }^{1,2,6,14,49}$ The majority of these cases does not present with spinal instability and does not require instrumented 
fusion. The literature suggests laminectomy, laminoplasty, or fenestration at the affected level (or levels) as valuable surgical techniques. ${ }^{1,5,6,14,32,49,62}$ A large retrospective study by Li et $\mathrm{al}^{32}$ compared the outcomes of laminoplasty and laminectomy. The authors described a $25 \%$ improvement with the former technique against an $83 \%$ improvement with the latter. Fenestration may be performed in situations in which the OLF is laterally located and not fused at the middle of the spinal canal, often presenting with radicular pain. 2,49

Adherence of the dura is reported in 11 to $62 \%$ of OLF surgeries. ${ }^{59}$ Meningeal involvement can often difficult the surgical procedure. ${ }^{32}$ Cerebrospinal fluid leakage following disruption of the dura mater is one of the major intraoperative complications. ${ }^{1,49}$ Cerebrospinal fluid (CSF) leakage can lead to CSF fistula formation, pseudomeningocele, meningitis, arachnoiditis and epidural abscess. ${ }^{63}$

Inamasu and Guiot ${ }^{64}$ recently conducted a systematic review concerning the factors that influence the outcome after surgery for OLF. The authors reviewed 31 articles, and suggested that gender, age, the level of the ossified lesion, the number of OLF-affected segments, the coexistence of an ossified posterior longitudinal ligament, OLF classification on CT, and the presence of a high intensity signal are unlikely to modify the outcome after surgery. They also suggested that the duration of the symptoms and the neurological score may influence the outcome. Altogether, the literature strongly suggests that the preoperative duration of the symptoms, ${ }^{48,49,55}$ the severity of the neurological deficit, ${ }^{48,49}$ and the presence of hyperintense signals ${ }^{6,15,65}$ in the spinal cord can influence the outcome. This was reaffirmed in a retrospective analysis of 85 cases conducted by $\mathrm{Li}$ et al. ${ }^{7}$ Surgical decompression, particularly through laminectomy, generally results in improvement or disappearance of the symptoms in most cases. ${ }^{2,6,14,32,49}$

\section{Conclusion}

Ossification of the ligamentum flavum has been well-established as a cause of myelopathy. The pathogenetic mechanisms of the disease are not well understood, but they most likely include different mechanical and biological factors. Although OLF is more common in Asian populations, it can also be present in different ethnic groups. We reported a rare case of thoracic OLF in a black patient. Symptomatic patients should be surgically treated.

\section{References}

1 Christiano LD, Assina R, Goldstein IM. Ossification of the ligamentum flavum: a unique report of a Hispanic woman. Neurosurg Focus 2011;30(03):E15

2 Ben Hamouda K, Jemel H, Haouet S, Khaldi M. Thoracic myelopathy caused by ossification of the ligamentum flavum: a report of 18 cases. J Neurosurg 2003;99(2, Suppl)157-161

3 Guo JJ, Luk KD, Karppinen J, Yang H, Cheung KM. Prevalence, distribution, and morphology of ossification of the ligamentum flavum: a population study of one thousand seven hundred thirtysix magnetic resonance imaging scans. Spine 2010;35(01):51-56
4 Okada G, Hosoi S, Kato K, et al. Case report 779. Carbonate apatite calcification of ligamentum flavum. Skeletal Radiol 1993;22(03): 211-213

5 Okada K, Oka S, Tohge K, Ono K, Yonenobu K, Hosoya T. Thoracic myelopathy caused by ossification of the ligamentum flavum. Clinicopathologic study and surgical treatment. Spine 1991; 16(03):280-287

6 Pascal-Moussellard H, Cabre P, Smadja D, Catonné Y. Symptomatic ossification of the ligamentum flavum: a clinical series from the French Antilles. Spine 2005;30(14):E400-E405

7 Li Z, Ren D, Zhao Y, et al. Clinical characteristics and surgical outcome of thoracic myelopathy caused by ossification of the ligamentum flavum: a retrospective analysis of 85 cases. Spinal Cord 2016;54(03):188-196

8 Pascal-Mousselard H, Smadja D, Cabre P, Raynaud M, Catonne Y. Ossification of the ligamenta flava with severe myelopathy in a black patient. A case report. Spine 1998;23(14):1607-1608

9 Mobbs RJ, Dvorak M. Ossification of the ligamentum flavum: diet and genetics. J Clin Neurosci 2007;14(07):703-705

10 Sakou T, Taketomi E, Matsunaga S, Yamaguchi M, Sonoda S, Yashiki S. Genetic study of ossification of the posterior longitudinal ligament in the cervical spine with human leukocyte antigen haplotype. Spine 1991;16(11):1249-1252

11 Koga H, Sakou T, Taketomi E, et al. Genetic mapping of ossification of the posterior longitudinal ligament of the spine. Am J Hum Genet 1998;62(06):1460-1467

12 Yayama T, Uchida K, Kobayashi S, et al. Thoracic ossification of the human ligamentum flavum: histopathological and immunohistochemical findings around the ossified lesion. J Neurosurg Spine 2007;7(02):184-193

13 Parekh HC, Gurusinghe NT, Perera SS, Prabhu SS. Ossification of the ligamentum flavum in a Caucasian: case report. Br J Neurosurg 1993;7(06):687-690

14 Xu R, Sciubba DM, Gokaslan ZL, Bydon A. Ossification of the ligamentum flavum in a Caucasian man. J Neurosurg Spine 2008; 9(05):427-437

15 van Oostenbrugge RJ, Herpers MJ, de Kruijk JR. Spinal cord compression caused by unusual location and extension of ossified ligamenta flava in a Caucasian male. A case report and literature review. Spine 1999;24(05):486-488

16 Toledo JA, Isseldyk FV, Re M, Garrote M. Ossification of the ligamentum flavum as cause of thoracic cord compression: Case report of a Latin American man and review of the literature. Surg Neurol Int 2013;4:119

17 Cabrera-Aldana EE, De la Garza Ramos R, Zuluaga Gómez A, Rosales-Olivares LM, Reyes-Sánchez A. Multilevel thoracic ossification of the ligamentum flavum in a Hispanic woman with achondroplasia. Spine J 2016;16(11):e749-e750

18 Chana JS, Afshar F. Thoracic spondylosis presenting with spastic paraparesis. Postgrad Med J 1996;72(846):243-244

19 al-Orainy IA, Kolawole T. Ossification of the ligament flavum. Eur J Radiol 1998;29(01):76-82

20 Gupta RK, Agarwal P, Kumar S, Surana PK, Lal JH, Misra UK. Compressive myelopathy in fluorosis: MRI. Neuroradiology 1996;38(04):338-342

21 Sushil P, Anant K. Ossified-calcified ligamentum flavum causing dorsal cord compression with computed tomography-magnetic resonance imaging features. Surg Neurol 1994;41(06):441-442

22 Jaffan I, Abu-Serieh B, Duprez T, Cosnard G, Raftopoulos C. Unusual CT/MR features of putative ligamentum flavum ossification in a North African woman. Br J Radiol 2006;79(944):e67-e70

23 Kruse JJ, Awasthi D, Harris M, Waguespack A. Ossification of the ligamentum flavum as a cause of myelopathy in North America: report of three cases. J Spinal Disord 2000;13(01):22-25

24 Gondim J, Ramos Júnior F. [Thoracic spinal cord compression at two levels due to ligamentum flavum calcification. Case report]. Arq Neuropsiquiatr 1998;56(02):312-316 
25 Uchida K, Yayama T, Cai HX, et al. Ossification process involving the human thoracic ligamentum flavum: role of transcription factors. Arthritis Res Ther 2011;13(05):R144

26 Yin X, Chen Z, Guo Z, Liu X, Yu H. Tissue transglutaminase expression and activity in human ligamentum flavum cells derived from thoracic ossification of ligamentum flavum. Spine 2010;35(20):E1018-E1024

27 Moon SH, Park SR, Kim H, et al. Biologic modification of ligamentum flavum cells by marker gene transfer and recombinant human bone morphogenetic protein-2. Spine 2004;29(09):960-965

28 Hayashi K, Ishidou Y, Yonemori K, et al. Expression and localization of bone morphogenetic proteins (BMPs) and BMP receptors in ossification of the ligamentum flavum. Bone 1997;21(01):23-30

29 Kong Q Ma X, Li F, et al. COL6A1 polymorphisms associated with ossification of the ligamentum flavum and ossification of the posterior longitudinal ligament. Spine 2007;32(25):2834-2838

30 Tanaka T, Ikari K, Furushima K, et al. Genomewide linkage and linkage disequilibrium analyses identify COL6A1, on chromosome 21 , as the locus for ossification of the posterior longitudinal ligament of the spine. Am J Hum Genet 2003;73(04):812-822

31 Tsukamoto N, Maeda T, Miura H, et al. Repetitive tensile stress to rat caudal vertebrae inducing cartilage formation in the spinal ligaments: a possible role of mechanical stress in the development of ossification of the spinal ligaments. J Neurosurg Spine 2006;5(03):234-242

32 Li F, Chen Q Xu K. Surgical treatment of 40 patients with thoracic ossification of the ligamentum flavum. J Neurosurg Spine 2006; 4(03):191-197

33 Yoshida M, Shima K, Taniguchi Y, Tamaki T, Tanaka T. Hypertrophied ligamentum flavum in lumbar spinal canal stenosis. Pathogenesis and morphologic and immunohistochemical observation. Spine 1992;17(11):1353-1360

34 Ono K, Yonenobu K, Miyamoto S, Okada K. Pathology of ossification of the posterior longitudinal ligament and ligamentum flavum. Clin Orthop Relat Res 1999;(359):18-26

35 Tomita K, Kawahara N, Baba H, Kikuchi Y, Nishimura H. Circumspinal decompression for thoracic myelopathy due to combined ossification of the posterior longitudinal ligament and ligamentum flavum. Spine 1990;15(11):1114-1120

36 Hukuda S, Mochizuki T, Ogata M, Shichikawa K. The pattern of spinal and extraspinal hyperostosis in patients with ossification of the posterior longitudinal ligament and the ligamentum flavum causing myelopathy. Skeletal Radiol 1983;10(02):79-85

37 Ehara S, Shimamura T, Nakamura R, Yamazaki K. Paravertebral ligamentous ossification: DISH, OPLL and OLF. Eur J Radiol 1998; 27(03):196-205

38 Kojima T, Oonishi I, Kurokawa T. Ossification of the ligamentum flavum in the thoracolumbar spine of young adults report of two cases. Int Orthop 1992;16(01):75-79

39 Ishida Y, Kawai S. Effects of bone-seeking hormones on DNA synthesis, cyclic AMP level, and alkaline phosphatase activity in cultured cells from human posterior longitudinal ligament of the spine. J Bone Miner Res 1993;8(11):1291-1300

40 Terakado A, Tagawa M, Goto S, Yamazaki M, Moriya H, Fujimura S. Elevation of alkaline phosphatase activity induced by parathyroid hormone in osteoblast-like cells from the spinal hyperostotic mouse TWY (twy/twy). Calcif Tissue Int 1995;56(02):135-139

41 Wang Z, Li XD, Li MQ Wang QP. Changes in basic metabolic elements associated with the degeneration and ossification of ligamenta flava. J Spinal Cord Med 2008;31(03):279-284

$42 \mathrm{Li} \mathrm{H}$, Jiang LS, Dai LY. Hormones and growth factors in the pathogenesis of spinal ligament ossification. Eur Spine J 2007; 16(08):1075-1084

43 Matsui H, Katoh Y, Tsuji H. Untreated hypophosphatemic vitamin D-resistant rickets with symptomatic ossification of the ligamentum flavum. J Spinal Disord 1991;4(01):110-113
44 Vera CL, Cure JK, Naso WB, et al. Paraplegia due to ossification of ligamenta flava in X-linked hypophosphatemia. A case report. Spine 1997;22(06):710-715

45 Epstein NE. Ossification of the yellow ligament and spondylosis and/or ossification of the posterior longitudinal ligament of the thoracic and lumbar spine. J Spinal Disord 1999;12(03):250-256

$46 \mathrm{Kim} \mathrm{TJ}$, Kim TH, Jun JB, Joo KB, Uhm WS. Prevalence of ossification of posterior longitudinal ligament in patients with ankylosing spondylitis. J Rheumatol 2007;34(12):2460-2462

47 Sato T, Kokubun S, Tanaka Y, Ishii Y. Thoracic myelopathy in the Japanese: epidemiological and clinical observations on the cases in Miyagi Prefecture. Tohoku J Exp Med 1998;184(01):1-11

48 Aizawa T, Sato T, Sasaki H, Kusakabe T, Morozumi N, Kokubun S. Thoracic myelopathy caused by ossification of the ligamentum flavum: clinical features and surgical results in the Japanese population. J Neurosurg Spine 2006;5(06):514-519

49 Aizawa T, Sato T, Sasaki H, et al. Results of surgical treatment for thoracic myelopathy: minimum 2-year follow-up study in 132 patients. J Neurosurg Spine 2007;7(01):13-20

50 Epstein N. Thoracic ossification of the posterior longitudinal ligament, ossification of the yellow ligament from T9-T12 with superimposed acute T10/T11 disc herniation: controversies in surgical management. J Spinal Disord 1996;9(05):446-447, discussion 447-450

51 Rivierez M, Vally P. [Ossification of ligamentum flavum unmasked by acute paraplegia]. Neurochirurgie 2001;47(06):572-575

52 Sagar H, Fernandez-Madrid F, Kupsky W. Rare cause of thoracic myelopathy: ossified ligamentum flavum. J Clin Rheumatol 2010; 16(07):326-329

53 Suojanen JN, Lipson SJ. Spinal cord compression secondary to ossified ligamentum flavum. J Spinal Disord 1989;2(04):238-240

54 Wiseman DB, Stokes JK, Toselli RM. Paraparesis in a black man brought on by ossification of the ligamentum flavum: case report and review of the literature. J Spinal Disord Tech 2002;15(06):542-545

55 Shiokawa K, Hanakita J, Suwa H, Saiki M, Oda M, Kajiwara M. Clinical analysis and prognostic study of ossified ligamentum flavum of the thoracic spine. J Neurosurg 2001;94(2, Suppl)221-226

56 Shiraishi T, Crock HV, Lewis P. Thoracic myelopathy due to isolated ossification of the ligamentum flavum. J Bone Joint Surg Br 1995;77(01):131-133

57 Omojola MF, Cardoso ER, Fox AJ, Drake CG, Durward QJ. Thoracic myelopathy secondary to ossified ligamentum flavum. J Neurosurg 1982;56(03):448-450

58 Sugimura H, Kakitsubata Y, Suzuki Y, et al. MRI of ossification of ligamentum flavum. J Comput Assist Tomogr 1992;16(01):73-76

59 Muthukumar N. Dural ossification in ossification of the ligamentum flavum: a preliminary report. Spine 2009;34(24):2654-2661

60 Miyasaka K, Kaneda K, Sato S, et al. Myelopathy due to ossification or calcification of the ligamentum flavum: radiologic and histologic evaluations. AJNR Am J Neuroradiol 1983;4(03):629-632

61 Muthukumar N, Karuppaswamy U, Sankarasubbu B. Calcium pyrophosphate dihydrate deposition disease causing thoracic cord compression: case report. Neurosurgery 2000;46(01):222-225

62 Sanghvi AV, Chhabra HS, Mascarenhas AA, Mittal VK, Sangondimath GM. Thoracic myelopathy due to ossification of ligamentum flavum: a retrospective analysis of predictors of surgical outcome and factors affecting preoperative neurological status. Eur Spine J 2011;20(02):205-215

63 Kalevski SK, Peev NA, Haritonov DG. Incidental Dural Tears in lumbar decompressive surgery: Incidence, causes, treatment, results. Asian J Neurosurg 2010;5(01):54-59

64 Inamasu J, Guiot BH. A review of factors predictive of surgical outcome for ossification of the ligamentum flavum of the thoracic spine. J Neurosurg Spine 2006;5(02):133-139

65 Kuh SU, Kim YS, Cho YE, et al. Contributing factors affecting the prognosis surgical outcome for thoracic OLF. Eur Spine J 2006; 15(04):485-491 